UDC $621.315 .61: 620.1 .001 .8: 621.316 .57$

\title{
有機物消弧材料の評価試験についての一研究 61-B25
}

\author{
正員 金 東 海 (上智大) \\ 正員神谷利雄 (上智大)
}

\section{1. まえがき}

真荷開閉器やカットアウトスイッチには, 多くの絶 緑材料が酎弧材や消弧材として用いら㧈ている。アス ベストセメント板, ジルコン磁器, ファイバなどは, 古くからよく用いられた耐弧材料であり，油，水，空

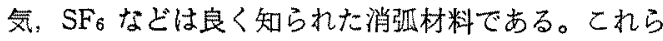
の材料は耐弧材または消弧材の単独の役目を受け持つ ことが多かった。しかし，近年高分子化学の発達によ つてメラミン樹脂，尿素樹脂，アクリル樹脂なよ゙のよ うに消弧力の強い材料が多く産出され，消弧材・兼耐 弧材として用いられるようになった。てれらの材料の 而弧材としての適否を判定するのに，耐アーク試験法 が確立されているが，消弧材としての適否の選択は経 験に頼っている。すなわち，材料を開開器に装着し て，実際に負荷開閉試験を行ない，定性的に良否の判 断を行なっている。ところが良と判断された材料で も，製造ロットの違いや製造時の天假などによってバ ラッキが大きく，工学的な因難に直西しているのが現 状である。従って消弧力を定性的ばかりでなく定量的 に判定できるような方法を見い出すとよは開閉器分野 における社会的要請の一つである。とのような観点か ら，基礎研究を行なっている研究者屯見受けられる。 例えば，Steel 氏ら(1)は円筒形の真荷開閉器モデルを 作り，いろいろな材料について実験し，消弧材料の消 耗量, 再起電圧, 引っばり強度, 膨脹率, 粘度などを 測定し，消胍過程を化学的に分析している。また， Niemeyer 氏(2) はアークと消弧材料間のエネルギー授 受に着目し，物理的にエネルギ一方程式や運動方程 式，質量保存式などを導き出している，更に Hettwer 民(3)消弧材料から放出されているガスを分析し，消 坬に有用なガス成予を明らかにしている。しかし，

A Method of Experimentally Evaluating Organic Materials for Arc-Quenching Capability. By Tung Hai Chin, Member \& Toshio Kamiya, Member (Department of Electrical and Ele. ctronics Engineering, Faculty of Science and Technology, Sophia University).

金東海：正員，上智大学理工学部

得谷利雄：正員，上智大学理工学部
各々にその研究成果はあるが，総合的試験法を礁立す るまでには至っていない。本論文は有機物消弧材料の 評価試験法の確立を目ざすものである。

消弧材料の試験方法にはいるいらなものが考えられ るが，次のような条件を满足するととが望ましい。 (1)装置が簡単であること，(2)湘定が容易であるこ と，(3)実験に再現性があること，(4)実験回数が少 なくてすむとと，（5）小量の奏鈳材料ですむこよ， (6)計算処理が容易であること，（7)各種材料間の相 対比較が容易であること, (8)汎用の負荷開閐器と構 造的に相似し, 試験結果から実用開閉器の性能の類推 が可能なとと，(9)経济的であるとと，等々でおる。

著者らは消弧力之相関のありそうな物理量しして， 次のようなあのがあると考えた。すなおち，(イ）ー クコンダクタンス，(口)アーク時定数，（八)再破㙹䉓 王，(二)消弧後の材料表面の絶縁抵抗，(ホ)材料の沿 面絶縁耐力，(へ)放出ガス成分，温度，熱伝導率之 導電率である。そこで，これらの項目の内，ひとまず (イ)〜(ホ)項目に注目し，とれらを测定するのに適し た奏験装置を試作した。本諭文は試験装置の製作過程 におりる諸考察，消弧材料中におりるアーク放電の安 定法，再現性の良い実験法，およびアーク放電諸定数 の計算法とアーク放電のシミュレーション，最後に諸 試料についての試験結果を記述したすのである。

\section{2. 㥶験装置および実験}

〈2・1〉アーク放電の安定化，試験装置は再現性 があり，電極材料の影響を受けずに，その特性を测定 でき, かつ武験結果が沉用の開閉器の奏目荷試験との 相対比較が容易であるような樌造が望ましい。実験の 再現性を良くうるための基本的に重要なととは安定な アーク放電の実現にある。とのような要望を実現する ための試料の形状は (1) 円筒状 ${ }^{(1)}$ ，（2)平板状の6の が考えられる。しかし前者はアーク放電の安定化が容 易になるなよ゙の利点はあるが，試料の製造が困難で， 試験方法も複雑になるので，多種多様な材料を試験す る装置としては適当しはいえない。従って，ここでは 後者を採択した。 


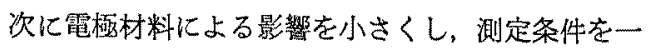
定とするためにアーク放電がある一定のアーク長のむ とで測定が行なわれた方が良い。徒って，アークの引 き延ばし方法を考元る必要がある。著者らは次们述心 る二つの方法について検討した。

(a) 磁気駆動方式の試験装置最初にアーク放 電の発生と測定在別々の場所で行なう方法を考えた。 そのために電極が開いて小電流によるてーク放電を発 生させ,この小電流のアーク放電を磁気駆動により一 定電極距離の別の場所任移させ，そこで所定の大電 流を重畳させていろいろの測定を行なった。測定を行 なう場所住平行に配置した試料の板にはさまれ，また アーク放電を安定させ, かつ,アーク長を一定にする 目的で,アーク放電の行く手に試料と同じ村質の安定 板が設けられた。しかし，ての方法で明らかになった ことはアアーク放電を安定板（片側にしか設けていな い）に押しつけると，アーク放電はか加って不安定に なり、アーク電生が激しく跳躍することである。この ようなアーク放電の振舞は有機物絶縁材料特有のあの であり，アスベストセメント板やアルミナ板の如き無 機質の材料については見られないので，多分に片側に しか配置されていない安定板からの蒸気放出に起因す るすのと考えられる。

（b）非駆動方式の試験装置上記の装置より, 片側に安定板をつけたり，安定板に押しつけたりする ことは，アーク放電を安定化させられないととが明ら かとなった。次の試みとして，同側に安定板を設け， アーク放電を安定板に押しつけない力式の装置を作っ た。図 1 は非押付方式の安定板を用いた装置の概形図

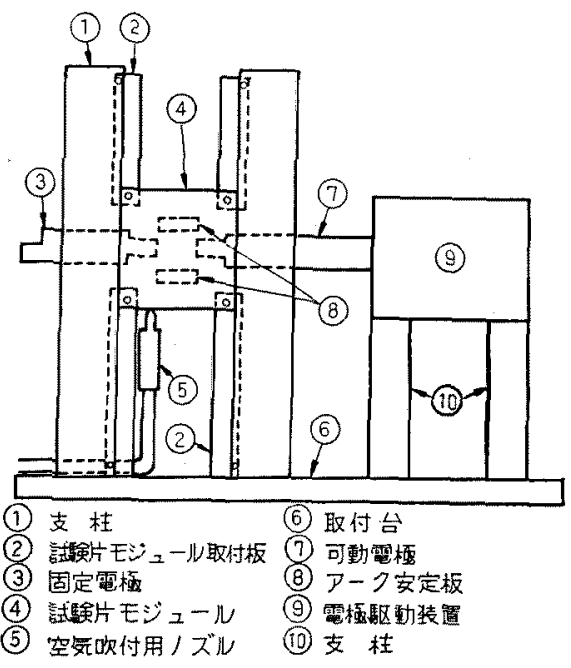

図 1 試験装置概形

Fig. 1. A overall view of testing equipment.
である。試料からなる試験片は取扱いの簡易化之㾞料 寸法定数の保持を目的にモジュールに組立ててから装 置化固定される。図2 はモジュールの詳細図である。 この試験片モジュールの中で,アーク放電を発生させ て試験を行なうととになる。ここで，洼置の操作順序 を説明する。最初に電極(3)(7)閉じた状態にしておき 電極間に 7 10A 0 初期電流を流す。次に可動電極 (7)を開く之，電極間に “種”となるアーク放電が発生 する(以後とのアークのととを種アークと呼かととに する)。可動電極が所定の位置に到達した時点で種ア 一ク電流に所定の测定電流を重轠して流し, 諸測定を 行なう。(8)はーク放電安定板である。安定板が電極 に接近し過ざると，図3(a)の测定電流重畳時のアー ク電生波形が示すようにアークはやはり不安定とな る。すし安定板の位固を適正汇調整すると，同図(b) のように非常に安定なアーク電生波形が得ら机る。以 下，本論文の実験においてはこの方式の装置を採用し た。とのようにして, 一組の試験片について上記の放 電試験を約 100 回繰返し，材料が消耗して消弧力が低 下していく様子を調べた。なお，(5)の空気吹付ノズル は每回試駼後のモジュール内残留ガスを清掃するため のあのであり，每試験瑷 15 秒間，モジュール內の清 揞を行なった。

$\langle 2 \cdot 2\rangle$ 実験装置の詳細次に本論文における実 験装置各部の詳細について説明する。実験装置は電極 駆彭部分，試験片モジュールと回路部分に分かれてお り，以下順を追って細部構造並びにそのような構造を 採用した経緯について説明する。

（a）電極構造 電極先端の形状の決定に際して は正負ともに平型，中央凸起型，丸型など種々の形状 で実験を行ない，比較検討を行なった。多数の実験結 果から次のような理由で図2（c）のような好型電極が 最適であると判明した。

（1）丸型にするとてアークスポットは大体電極の中

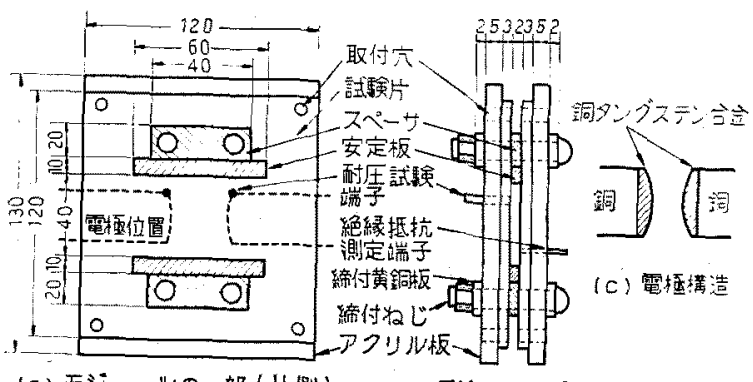

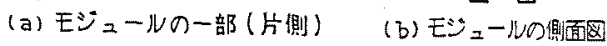

困 2 試験片モジュール

Fig. 2. Test piece module, (a) front view, (b) side view, (c) shape of electrode. 


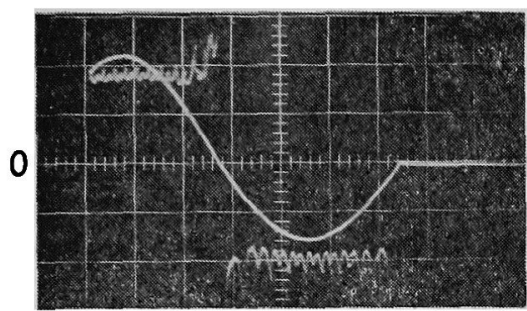

$e: 100 \mathrm{~V} / \mathrm{div}, i: 200 \mathrm{~A} / \mathrm{div}$, 時間: $2 \mathrm{~ms} / \mathrm{div}$

(a) 不安定なアーク

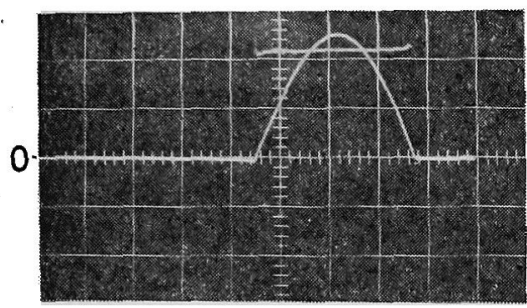

$\boldsymbol{e}: 100 \mathrm{~V} / \mathrm{div}, i: 200 \mathrm{~A} / \mathrm{div}$, 時間: $2 \mathrm{~ms} / \mathrm{div}$ (b) 安定なアーク

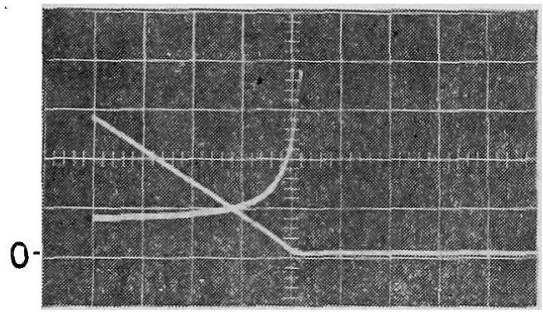

$e: 400 \mathrm{~V} / \mathrm{div}, i: 20 \mathrm{~A} / \mathrm{div}$, 時間: $50 \mu \mathrm{s} / \mathrm{div}$

(c) 波形 (b) の電流零点直前の㹡大波形

図 3 消弧室内におりるアーク放電の電巵 および電流波形

Fig. 3. Voltage and current waveforms of arc discharge caused in the quenching chamber.

央部で発生する。(2)アークスポットが少し移動して もアーク長はあまり変らない。(3)電極先端に鉰タン グステン合金を使えば，電極の消耗量が少なく，多数 回の実験にわたってアーク長をほぼ一定に保てる。な お，実験結果に及ぼす開極長の影響が大きく，本実験 では全開極長 $45 \mathrm{~mm}$ に対して $0.1 \mathrm{~mm}$ の精度で開極 長を調整できるよう微調整装置を固定電極側に設け た。すなわち，0.1 $\mathrm{mm}$ は $45 \mathrm{~mm}$ に対して $0.2 \%$ で あり，オシロの精度 $3 \%$ に対して十分な精度である。

（b）試験片および安定板 試験片モジュールは 図 2 亿示す如く, 厚さ $3 \sim 5 \mathrm{~mm}$ の試料を一辺の長さ $120 \mathrm{~mm}$ の正方形に加工したものを試験片として組立 てた。試験片は実験中に熱によって变形しないよう に, 厚さ $5 \mathrm{~mm}$ のアクリル板で裹打ちし, 二枚の試験 片の間にスペーサと安定板をはさみ，ビスナットで堅 固に締付け，試験片間隔を一定に保持した。試験片間
隔の变動もアーク電圧や時定数の測定に大きな影響を 与える。例えば，試験片間隔に扔ける $0.1 \mathrm{~mm}$ の変 動(間隔 $2 \mathrm{~mm}$ に対して 5\%) がある場合においては 約 $70 \mathrm{~V}$ のアーク電圧の変動（最大電圧 $e_{m}=1,700 \mathrm{~V}$ 約の 4\%)となって現われる。従って, 試験片の間隔を 正確任保持することが大切で，ここでは黄銅製のスぺ 一サを厚みにして $0.02 \mathrm{~mm}$ 以上の精度で精密加工し たにこ机は試験片間隔誤差が $1 \%$ 以下であることを意 味する)。一方, 安定板の方はスペーサよりひわずか に薄くし，試験片之同質の材料を使用した。安定板の 長さと位置は，アークが最も安定するように決められ た。本装置の場合においては安定板の位置は上下とも アークの中心より $20 \mathrm{~mm}$ 離㣗た場所である。上下い ず机の安定板が欠けても，アーク放電は不安定とな り, 試験片外に飛び出したり, アーク電圧が跳躍した りする。安定板の長さは開極長よりも長く, $60 \mathrm{~mm}$ 之 した。これによって，材料より発生する蒸気による了 一ク放電のとじ込みを確実にできる。

(c) 沿面抵抗試験用電極および耐圧試験用電極 試験片にはそれぞれ沿面抵抗測定用之耐圧試験用の 電極が埋込まれた。電極の設置場所は次のような事項 を考慮して選ばれた。(1)測定点はアーク特性に影響 を与えず，しかもアークが接触し，カーボンの付着量 の比較的多い場所が望ましい。(2)放電の中心部はア 一クが直接接触するので試料の蒸発が盛んであり，て のような場所代試験用電極を設汸る試料の蒸発量に 影響し、ひいては消弧特性汇影響を及ぼす恐れがあ る。(3)中心部におけるカーボンの付着量は周辺部に 比べてでく少量である。(4)安定板の近くにおいては カーボンの付着量は多いものの，ほとんどアークは接 触せず，主電極からの離隔距離も長い。しかも実用の 開閉器にはない，一種の吹き溜りのような特殊な場所 であるので，ここでの測定は好ましくない。このよう な事項を考慮して，沿面抵抗測定用電極は図 2 のよう に0.8 $\mathrm{mm} \phi$ の銅針 2 本を $20 \mathrm{~mm}$ の距離を㧊いてアー ク放電中心より安定板側へ $10 \mathrm{~mm}$ の位置に試験片に 埋込んだ。また，反対側の試験片には開極時における 主電極間耐圧試験用の $5 \mathrm{~mm} \phi$ の銅電極を $45 \mathrm{~mm}$ の 間隔をおいてアーク放電中心より，安定板側へ $10 \mathrm{~mm}$ 離れた位置に埋込んだ。主電極の開極長む $45 \mathrm{~mm}$ で あるので，耐電圧試験用電極济ちょうど主電極にかく れる。耐電圧試験用電極の先端は平らにし, 試験片の 表面と同一面となるように調節して，接着剤で試験片 に固定した。

アーク定数測定試験 10 回どとに耐圧試験を行なっ た。試験に際しては直流試験電告を零より $6 \mathrm{kV}$ まで 
徐々に約 $30 \mathrm{~V} / \mathrm{S}$ の割合で上昇させた。一度絶縁破壊 が起ると試験片表面化付着しているカーボンが焼失し たり，飛散したりして，沿面抵抗の值が著しく変るの で，上述の二種類の電極は分離する必要があった。ま た，而電庄試験においては試験電極之試験片表面之の 接触を良くし，破壊したときのアークによる電極消耗 の影響を少くするために太い電極使用した。なお， 放電試験中はとれらの麗極には何も接続しないでオ一 プン状態としておいた。

〈2.3〉 試験回路陚験回路は図 4 飞示す通り, 主回路之補助回路および保護回路で構成されている。 $E_{1}$ は種アーク放電用補助電源であり，電纴は $3 \mathrm{kV}$ から $20 \mathrm{kV}$ まで段階的化变え得る。R、は種アーク放 電の電流值を決める抵抗であり，電流值は主電極が完 全開極時においても種アーク放電が消えない程度に調 整される必要がある。 $L_{1}$ はアーク放電安定用インダ クタンスである。主回路には装置の都合上 $216 \mu \mathrm{F} の$ コンデンサと $25 \mathrm{mH}$ のインダクタンスを用い, 半周 期約 $7.5 \mathrm{~ms}$ の減衰振動電流が得られる。コンデンサ バンクは電源 $E_{2}$ によって充電され，充電電圧は約 6 $\mathrm{kV}$ まで調整可能で, その際の主電流の最大波离值は 約 $500 \mathrm{~A}$ である。S は保讙用ギャップ，SW $2, S W_{3}$ は プランジャ一形の電酳スイッチである。スイッチ類の 操作装置および波形観测用卜りガ発生装置は試験關始 命令信号を送ることによって，予め決められたシーケ ンスに従って自動的に作動するように設定した。

$\langle 2 \cdot 4\rangle$ 試験方法実験装置の操作手順は $\langle 2 \cdot 1\rangle$ （b）節において述べた通りで，アーク電任波形は図 3 (b)洒されている。アーク電王の值はアーク電流が

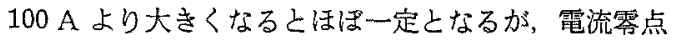
前後の $i<100 \mathrm{~A}$ の籍囲では大きく変化し，アーク放 電についての多くの情報が含まれている。この領域の

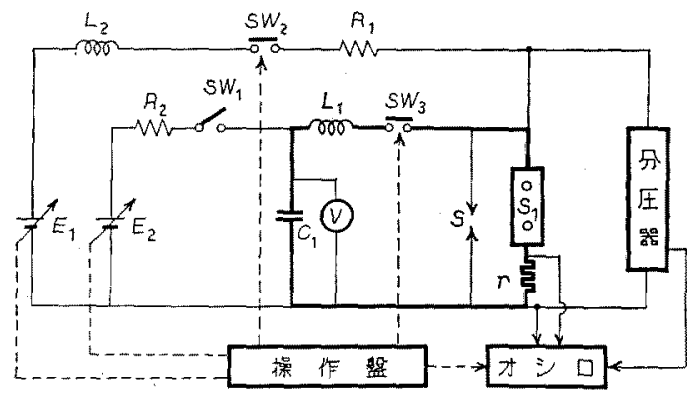

$L_{2}=1.1 \mathrm{H}, 48 \Omega, L_{1}=25 \mathrm{mH}, C_{1}=216_{4} \mathrm{~F}, R_{1}=150 \Omega$ $R_{2}=10 \mathrm{k} \Omega, r=0.01 \Omega$

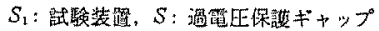

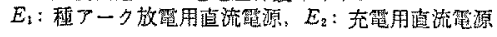

园 4 試験回路

Fig. 4. Testing circuit.
現象が良く観測できるように同期装犆を製作した。 図3(c)は乙のようにして撮影した電圧, 電流の拉大 波形の一例である。このような波形を放電試験でとに 写真撮影し，電流零点值前のアーク電圧のピーク値や その発生時刻などを測定し，そしてこれらの值が試験 回数の增加に伴って変化していく様子を調べた。ま た，放電試験 10 回ごとに沿面抵抗之耐電圧試験を行 ない，試験片表面の劣化の㥞子芫調べた。試験片は実 験の前上後拉よび途中において計三回，重量を計り， アークによる消耗の様子も調べた。

本試験に扔いては, 测定データに大きな影響を与え るパラメータとして下記のものがあることが予備試験 汇よって明らかとなった。すなわち（1)試験片間 隔，(2)全開極時沈おける電極開極長，（3）充電電王 である。乙れは本試験方法において, 試験電流か $L C$ 回路の放電によって生成されており，てれらのパラ メータの変化は電流值その他に影響を与えるからであ る。徉って, とれらの值を一定値に保つことは大変重 要である。てれらの内(1)については試験片をモジュ 一ル状に作るととによって間隔を一定値に保つこよが できた。(2)の電極長については，電極が可動部分を 有し，かつ消耗を来たすので，最杂不正確になりがち である。これらの弱点を克服するため, 前者代詨して は電極開極時間を十分に取る $(54 \mathrm{~ms})$ ととによって幾 械的振動などによる開極長に関連する誤差の発生を防 止し, 後者に対しては電極先端に銅タングステン合金 を用いて消耗量を減らし，微調整蓄置を設けて開極長 の常時監視, 修正することで詨芯した。(3)について は高精度のディジタルボルトメータで充電電巵を有効 数字三けたまで正確に電圧を設定した。

試験片の寿命, いいかえれば消弧力を維持可能な試 跧回数は電極の幅之開極長, 試驗片間隔長, 電流の波 高值および持続サイクル数などのパラメータによっ て左右される。また，試騒片表面には製造工程におい て剝離剤が混入している場合が多く, 最初の数回方る いは十数回程度はこれらの影響を受けることも予想さ れる。従って試験回数をあまり少くすることる好まし くない。本実験では予備試験により試験回数が100回 前後で一通りの特性試験が終えられるように開極長を $45 \mathrm{~mm}$, 試験片間隔を $2 \mathrm{~mm}$, 充電電圧を $5,900 \mathrm{~V}$ K 設定した。すなわち，適正に設定された条件のもとで は最初の 20 回程度までは半サイクル（最初の電流零 点)ですぐ消弧するだけの能力を持つか，100 回目前 後になるとアーク放電が 2 ー サイクル持続するほど

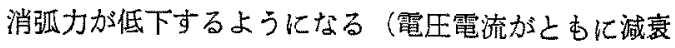
振動であるので，2〜3サイクル持続するこよはひど 
い消弧力の低下を意味する)。従って, 100 回程度で赛 験を打切っても十分に材料の優劣判定ができるだけの データが得られる。なお，とれは一種の寿命加速試験 法上考えることができる。実際の装置では，開極加ら 消弧までの時間が回を追って徐々にふえるので，本䒠 験での寿命之異なることは言うまであない。

\section{3. アーク放電定数の測定理論}

図3のアーク電王電流写真加ら香明ら加のうに, 本試験におけるアーク放電は非常に安定でばらつきも 少ないので，放電諸定数の測定む正確に行なえる。こ こで，試験結果の説明に先立って，まず放電諸定数測 定に関する理論的襄付けについて检討する。アーク放 電の数学的モデルはいろいろ考察されているが(5)/7), こてでは(1)式に示す Yoon 氏のモデルを用いる(4)。 但し，式中の $G$ はアーク放電のコンダクタンスで， $G$ s はある電流値における定常アークが取るべきコンダク タンス值で, 以下定常值と呼ふとととし， $\theta$ はアーク 放電の熱的時定数である。

$$
\frac{d G}{d t}=\frac{1}{\theta}\left(G_{s}-G\right)
$$

次にアーク電丕の定常特性として Ayrton 夫人の 式の第二項まで考えて (2)式のように仮定し， $A$ 上 $B$ は定数とする。

$$
e_{s}=\frac{A}{i}+B
$$

そして，(3)式に示す電流 $i$ をーク放電に流すと アーク放電の振舞は $(4)$ 式で定義される。但し， $u(t)$ は単位ステップ関数とする。

$$
\begin{aligned}
& i=I_{m} \sin (\omega t) \cdot u(t) \ldots \ldots \ldots \ldots \ldots \ldots \ldots \\
& \frac{d G}{d t}+\frac{G}{\theta}=\frac{\left\{I_{m} \sin (\omega t) \cdot u(t)\right\}^{2}}{\theta \cdot\left\{A+B \cdot I_{m} \sin (\omega t) \cdot u(t)\right\}}
\end{aligned}
$$

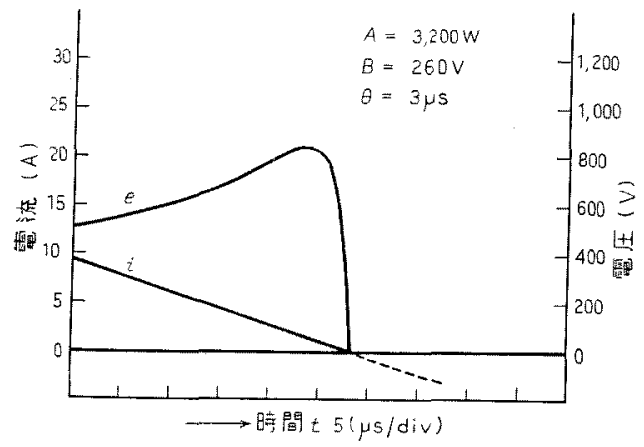

図 5 計算によるアーク特性（第 1 回目の 電流零点直前の電圧電流波形)

Fig. 5. Calculated arc dynamics.

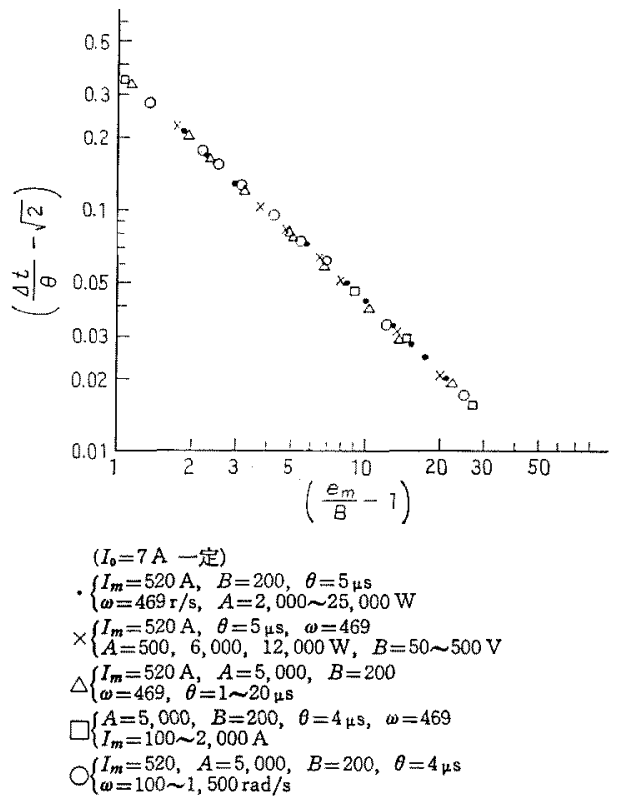

図 6 規格化した時定数とアーク電圧の関係

Fig. 6. The normalized time constant vs. arc voltage.

(4)式の一般解は (5)式で示される。

$$
G=e^{-(t / \theta)} \cdot\left[\int \frac{I_{m}^{2} \sin ^{2}(\omega t) \cdot e^{(t / \theta)}}{\theta \cdot\left\{A+B I_{m} \sin (\omega t)\right\}} \cdot d t+K\right]
$$

しかし（5)式中の積分項は皘分不能であるので， （4）式を数値的纪解いて，アーク放電の電压電流波形 と放電諸定数との関係を調べた。すなわち，(4)式中 ○ $1_{n}, \omega, A, B, \theta$ 亿適当な数值を設定してルンゲク ッターギル法で計算すると図 5 の上うな電圧電流波形 が得られた。この図は最初の電流零点付近の電圧電流 波形を描いたすのであり，電流零点付近に発生する最 大アーク電任を $e_{m}$, 電流零点加ら測った最大アーク 電圧時点までの時間を $\Delta t$ とする。次汇定数の設定値 をいろいる変えて計算し，乙の結果加ら $(\Delta t / \theta)$ と $\left(e_{m} / B\right)$ の関係を求めてみる上図6の上うな関係が得ら れた。すなわち，すべての設定条件 $\left(A, B, \theta, \omega\right.$ と $\left.I_{n}\right)$ に対して，その結果は活同一の直線上棌るととが 明らかとなった。ての直線を実験式化すると(6)式が 得られる。

$$
\frac{\Delta t}{\theta} \fallingdotseq \frac{0.35}{\frac{e_{m}}{B}-1}+v^{2}
$$

この式で $B=0$ とおくと， $\Delta t / \theta=\sqrt{2}$ となり，Mayr 氏のモデルなどに招いてよく知られた関係が得ら机 
る(5)(6)。いせかえれば，(6)式は Mayr 氏のモデルで アークの定常特性として $e_{s}=\mathrm{A} / i+B$ とした場合の時 定数の関係式亡考えられる。なお， $B$ はア一ク電流が 十分に大きい時点のアーク電圧 $e B$ にほぼ等しいので (6)式は $e_{m}, B, \Delta t$ を測定すれば, 時定数 $\theta$ が求め られるととを示す。

一方，（1)式を変形すると（7) 式が得られる。

$$
\frac{1}{i} \cdot \frac{d i}{d t}-\frac{1}{e} \frac{d e}{d t}=\frac{1}{\theta}\left(\frac{e}{e_{s}}-1\right)
$$

アーク電圧のピーク時点においては $d e / d t=0$ である ので，との時点での電流 $i$ の変化を直線とみなして， $i \cong I_{m} \cdot \omega \cdot t$ と置けば( 8$)$ 式が得られる。

$$
-\frac{I_{m} \cdot \omega}{e_{m}}+\frac{I_{m} \cdot \omega \cdot \Delta t}{e_{m} \cdot \theta}=\frac{1}{\theta} \frac{\left(I_{m} \cdot \omega \cdot \Delta t\right)^{2}}{\left(A+B I_{m} \cdot \omega \cdot \Delta t\right)}
$$

(8)式は $A$ について整理すると（9)式となる。
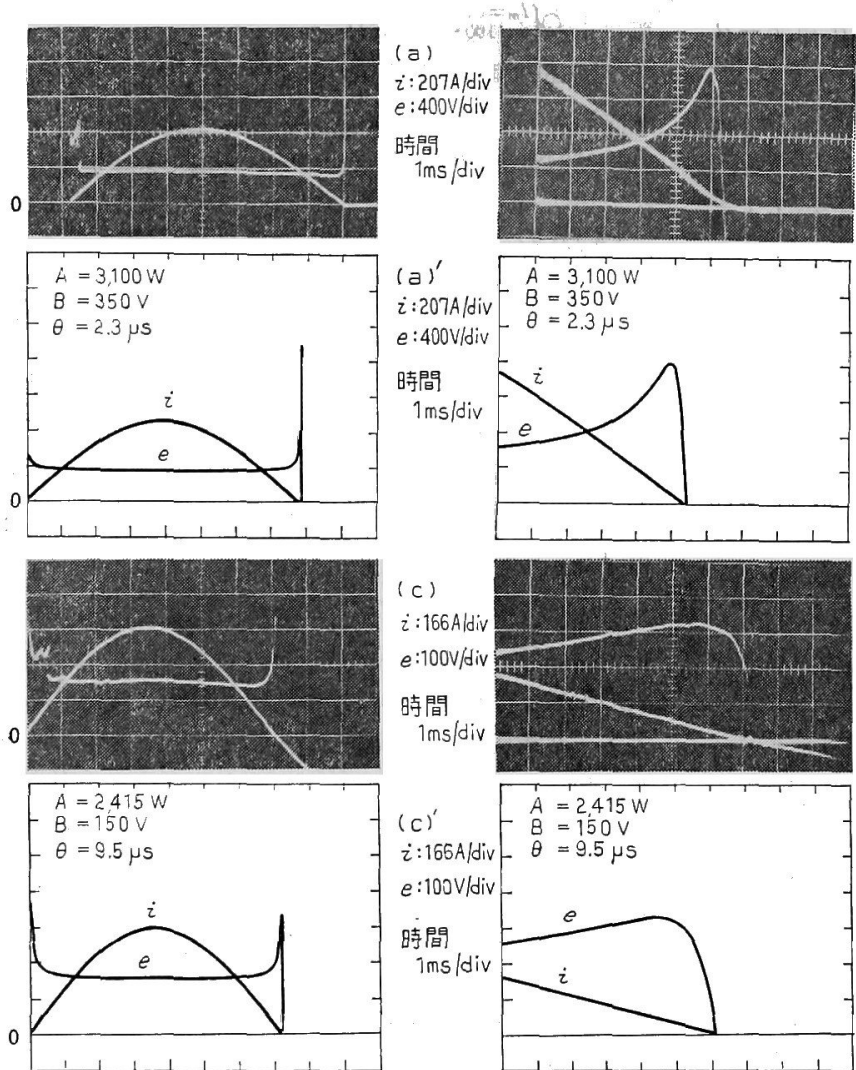

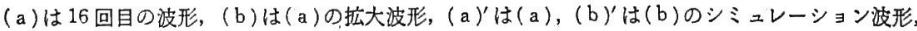
(c) は 98 回目の波形, 以下同粎

図 7 アセタールコポリマ中におけるアーク放電の電圧電流波形 およびシミュレーション波形

Fig. 7. Voltage and current waveforms of arc discharge caused in acetal copolymer and it's simulations. (b)

$i: 2.65 \mathrm{~A} / \mathrm{div}$ $e: 400 \mathrm{~V} / \mathrm{div}$

時間

$10 \mu \mathrm{s} / \mathrm{div}$

(b)

$i: 2.65 \mathrm{~A} / \mathrm{div}$ e: $400 \mathrm{~V} / \mathrm{div}$

時間

10us/div

以上のようにして (1) 式と (2)式を定義するアーク 放電定数 $A, B, \theta$ は電圧電流波形におりる特定の值 $e_{m}, \Delta t, I_{m}, e_{B}$ (最大電流時点におけるアーク電圧) 长めることが可能となる。

\section{4. 浮遊容量の影響と放電シミュレーション}

前節においては，アーク定数の求め方について説明 Yoon 氏のモデルが実際のアーク放電をどの程 集を行なった。例えぱ図 7 は消弧材として広く用いら れているアセタールコポリマ(Acetal Copolymer, 商 品名・ジュラコン) を試験片とした場合のアーク電圧

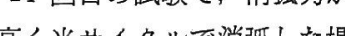
高く半サイクルで消弧した場 合の波形である。（b)は（a ) の時間軸を延ばしたものであ り，これを見ると $e_{m}$ 加高く， $\Delta t$ が小さい。これに対して (c)と (d)は 98 回目の試験 波形で， $e_{m}$ が低く， $\Delta t$ あ長 い。乙れは消弧力が極端に低 下した状態である。各波形よ りデータを読み取り，前記の 方法によりアーク定数を求め た。次に(1)〜 (5) 式に従。 てシミュレーションを行なう 之, 図 $7(a)^{\prime} \sim(d)^{\prime}$ に示す如 く，実験波形と極めて相似す る電圧電流波形が得られる。 後述する一部のずれ（原因が 明らかにされ，修正が可能） を除けば，実験波形と計算波 形とのずれはほとんど $10 \%$ 以内にとどまてっいる。てれ より Yoon 氏のモデルは本稿 の装置の中で点ぜられている アーク放電に対して，極めて 高い模擬性を持つととが明ら かである。

しかし, 波形を詳しく観察 すると，疑問となる点が見つ かり，しかも，乙れがアーク 定数の決定に大きな影響を及 
活す個所ですある。てれは図7（b）に見られるよう に, アーク電流の変化が雾点の直前で直線よりはずれ ることである。そのために $\Delta t$ の值の決定に大きな支 障をきたすことになる。しかし，詳しく現象を分析し た結果，ての電流のずれは電極部分の浮遊キャパシタ ンスの影響によるととが明らかとなった。すなわち， (b)罒のような消弧性能の高い放電の場合, 零点直前 のアーク電圧の変化率 $d e l d t$ が大変に大きい。乞のた めに，浮遊静電容量に蓄えられていた電荷がアーク放 電に放出されて，電流雾点を遲らせるととになる。従 ってアーク放電のシミュレーションにおいては浮避容 量の影響を考慮化入れる必要がある。また，零点直前 ではアーク電圧そのあのも高いために，電流波形がそ の影響も受けるので，アーク電圧む考慮に入れる必要 が起った。図8は実験回路のすべての要素を記入した 最終的なシミュレーション回路である。なお，浮避容 量の実測は水銀リレーと既知インダクタンスを用い て, $L-C$ 振動の原理により測定した。本諭文の装置で はその值が $130 \mathrm{pF}$ である。

因 9 は上記回路に対して行なったシミュレーション 波形である。浮遊容量のために電流零点がずれて, 直線的電流変化の場合上比較して, $\Delta t$ が $\delta t$ の分だけ
增加する。幸いに，電圧が最大となる点においてては， $d e l d t$ 汃零となるので，この時刻 $T_{1}$ における電流 $I_{1}$ は浮遊容量の影響を受けない。徉って, 浮遊容量が存 在しない直線的電流变化を仮定し，最大電圧点上り十 分前の任意の時刻 $T_{2}$ における電流值 $I_{2}$ をとり, 浮 遊容量が存在しない場合における $\Delta t$ の正しい檤を次 式代基づいて計算するととができる。

$$
\frac{I_{1}}{\Delta t}=\frac{I_{2}-I_{1}}{T_{1}-T_{2}}
$$

\section{5. 実験結果および検討}

以上に拉いて，試駼片中に括りる不安定なアーク放 電の原因を解明し，その安定方法，およびその放電偟 関連する諸定数の測定法について説明した。次にて机 らの方法に基づいて，各種試料について試験を行な い，それらの試料の消弧性能の判定法についての檢討 を試みた。試験は消弧材料として広く用いら机ている アセタールコポリマとユリア樹脂について行なった。

图10はアセタールコポリマについて実験した結果 であり，同図(a)は試験回数の增加に伴って变化する 熱時定数 $\theta$ の様子を示すが, 初加 10 回程度は下向 曲線を描いて低くなるが 10 回を過ざるころから安定

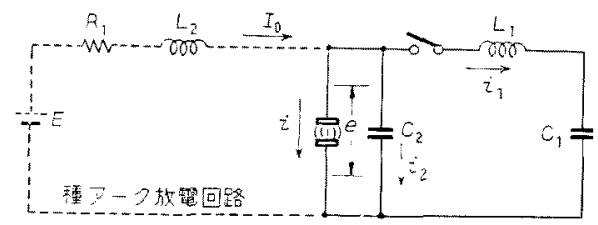

$L_{1}: 25 \mathrm{mH}, L_{2}: 1.1 \mathrm{H}, C_{1}: 216 \mu \mathrm{F}, C_{2}: 130 \mathrm{pF}$ $R_{1}: 150 \Omega, E: 5,900 \mathrm{~V}$

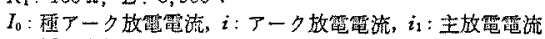

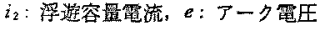

図 8 シミュレーション回路图

Fig. 8. Circuit model used for simulation.

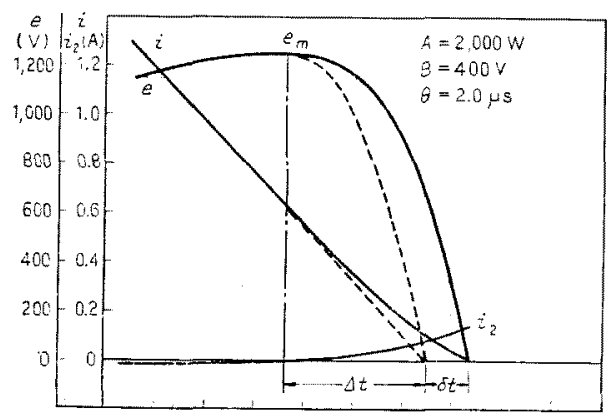

图 9 浮遊静霄容量の影暨を考虑した

$$
\text { シミニレーション波形 }
$$

Fig. 9. Simulation waveforms under the influence of stray capacitance. (a)

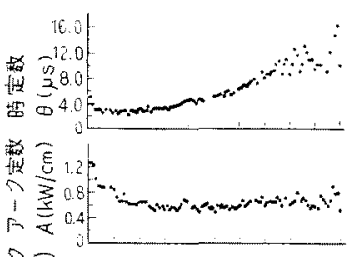

(c)

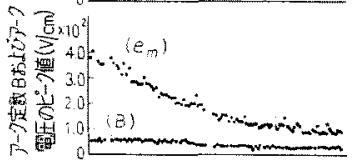

(d)

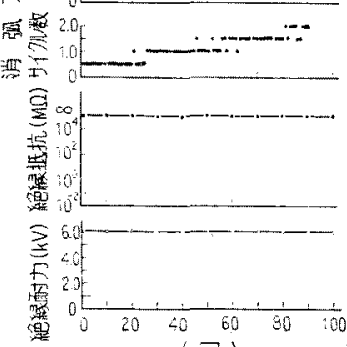

(可)

(a) 㷫時定数，(b) $T$-ク定数 $A$ ，

(c) $T$-ク定数 $B$, (d) 消䛇サイク儿数

(e) 绝䜌抵抗, (f) 絶縁酎力

図 10 アセタールコポリマの アーク定数

Fig. 10. Variation of arc constants of acetal coplymer.

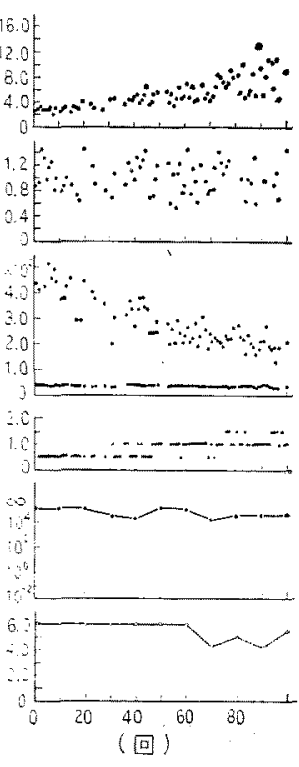

区 11 בリア能脂の アーク定数(园の説 明は图 10 参照)

Fig. 11. Arc constants obtained for urea resin. (for description see Fig. 10) 
期に入り，25 回程度まで持続する。その後は增力に 転じ，やがて加速度的に增加していく。70回を過ざ るころからバラッキが大きくなる。これは試料の消耗 が進行し，試験片の中心部分の間隔が広がりかつ不均 一化し，アーク放電の点弧位置が不確定化するためと 教えられる。同図(b)はアーク定数 $A$ を示す。同図 (c)はアーク電圧のピーク值 $e_{m}$ (単位長当りに換算) 㧍よびアーク定数 $B$ を示主。両方ともに試験の進行 に従って一粎低下する傾问にある。定数 $A$ は Mayr 氏に上れば単位長当りの損失となるが，最初の十数回 を除いて，活略一定値を保つ。こ机はアーク放電の太 さが変ってる損失があまり変らないことを意味する。 同図(d)は遮断サイクル数であり，25 回まではほと んど半サイクルで切れている。25回を過ぎると 1 サ イクルとなるが，境界点のバラツキは非常に少ない。 これに対して1サイクルから1.5サイクルに移るとき はバラッキが大きくなり，境界領域の帯が 15 回程度 となっている。1.5 サイクルから 2 サイクルに移ると きも同様である。同図(e)《は絶緑抵抗測定端子間で 測定した試料表面の絶縁括抗の值が示されているが， その值はほとんど無限大である。同図( f ) は耐圧試験 結果を示し， $0 \sim 6 \mathrm{kV}$ の直流電圧を印加したが破㙲し なかったので白丸で示してある。とれに対して，他の

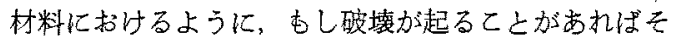
の電正值を黑丸で示すとととする。これらのグラフに は, 所々，データが欠落している場所があるが，そこ はデータを取りをこなったところである。

図11はユリア樹脂についてのデータである。ユリ ア樹脂屯，現在広く消弧材として用いら机ているが， アセタールコポリマと比較して次のような特徽があ る。すなわち，定数 $B$ を除いて時定数 $\theta ， 了 一 ク$ 電圧 のピーク值 $e_{m}$ および定数 $A$ は共にバラッキが大変大 きいとと，また試駼が進むにつれて，絶縁特性が低下 するととである。なお，データにバラッキがあって む，毎回の試験は安定なアーク放電が得られた。とと ろか洒者の消弧特性を比較した場合，ユリア樹脂のア 一ク定数は数值的にバラッキがあるけ机ざも，全体と してアセタールコポリマの数值より香良い側にある。 例えばユリア樹脂の $\theta$ の值はばらついているが，大 きい方の值ですてセタールコポリアのそ机之同程度で 苛り，平均值としては小さくなる。従って，ユリア樹 脂はナセタールコポリマよりは良い消弧性をむつこと になる。このととは消弧サイクル数（図d）のデータ からあ読み取るととができる。方，表面絶縁耐力の 点でスリア樹脂は難点があるようである。なお，定数 Bについてはユリア樹脂の值がほぼ一定で低いが，消
弧性に及ばす影響は $\theta$ とAはどではないようである。

\section{6. 結 論}

有機物消弧材料の試験法の確立を目ざして，装固の 最適構造，ならび測定値より必要な物理定数の導出 方法などについて初步的研究を試み，その結果次の上 うな成果が得られた。

（1）試験片と安定板で围われた空間において，非 常に再現性の良いアーク放電の安定法が得られ、アー クコンダクタンス, アーク時定数, 最大アーク電圧, 再破壊電圧; 材料表面の絶縁抵抗などが測定可能とな った。

（2）上記試験空間において点ぜられたアーク放電 に対して，Yoon 氏のモデルによるシミュレーション は実験結果と極㫰い一致が見られた。

（3） アーク放電の定常的電代電流特性 $e_{s}=A / i$ $+B$ 之仮定した場合に扰讨るア一ク定数 $A, B$ およひ 熱時定数 $\theta$ を実験データより算出する方法を確立し た。これによって消弧性能の定量的判定基準が得られ る見通しが立った。

以上の通り，試験法の確立に向的て大きな前進をな し得たが，な枋多くの未解決の閣題か残され，今後の 研究が引き続き必要である。例えば，アーク放電諸定 数之遮断特性之の相関，試験装置之実装置之の対応性 などを明確にしなけ机ばならないし，試験法の簡易化 あ棓る必要がある。

最後に，研究の助言をいただいた OHT技術士事務 可の大森豊明氏，材料など多くの助力をいただいた日 本ポリプラスチック(株)の高野菊雄氏，また実嗝汇努 力した卒業生の小泉 潤氏(現在・本日技研)，金子敏 彦氏（現在・東芝機械）汇深く感謝する。

(昭和 60 年 3 月 29 日受付)

\section{文献}

(1) R. B. Steel, et al.: "Arc Quenching Materials for Load. Break Separable Insulated Connectors" 7 th TEEE/PES Transmission and Distribution Conference and Exposition, April 1, 6 (1979)

(2) L. Niemeyer: "Evaporation Dominated High Current Arcs in Narrow Channels" IEEE Trans. Power Apparatus Sys. PAS-97, 3 (1978)

(3) P.F. Hettwer: "Arc-Interruption and Gas-Evolution Characteristics of Common Polymeric Materials" ibid. PAS101, 6 (1982)

(4) K.H. Yoon: "A Study of the Dynamic Response of Arc" ibid, PAS-69, 12, 1002 (1963)

(5) O. Mayr: "Uber die Theorie des Lichtbogens und Seiner Ioschung" E.T.Z. 49/50, 645 (1943)

(6) O. Mayr: "Beitrage zur Theorie des statischen und des dynamischen. Lichtbogens" Archiv für Elektrotechnik $7,12,588$ (1943)

(7) A. Morris Cassie: "Arc Rupture and Circuit Severity" CIGRE Rep-102, 1 (1939) 